\section{Status and conditions of} small- and medium-sized enterprises as predictors in empowering rural communities in Samar Island, Philippines

\author{
Asterio Tenedero Miranda \\ Department of Taxation, Keimyung University, Daegu, South Korea, and \\ Juneth Lourdes Fiel Miranda \\ Keimyung Adams College, Department of International Business, \\ Keimyung University, Daegu, South Korea
}

Small- and medium-sized enterprises as predictors

Received 15 December 2017 Revised 9 February 2018 Accepted 10 February 2018

\begin{abstract}
Purpose - This study aims to determine the status and conditions of small and medium enterprises (SMEs) as predictors in empowering the rural communities of Samar Island, Philippines. Specifically, it aimed to describe SMEs' organizational variables, and assess their conditions in terms of membership/ ownership structure; leadership; policies, systems and procedures; resource mobilization; linkages and networking; communication systems; and awards and recognition; determine the level of empowerment of rural communities with SMEs along the aspects of material, perceptual and relational changes; and find out whether significant relationship exist between the organizational variables and the level of empowerment.
\end{abstract}

Design/methodology/approach - The study is a descriptive survey that utilized structured survey questionnaires, personal interviews and dialogues with the respondents in the actual data collection. The survey involved 18 SMEs from the rural communities of the 12 municipalities from the 3 provinces of Samar Island, as study samples - 6 coming from each province with 2 SMEs in every sub-sector of trading, manufacturing and services. Out of 270 respondents, 256 (94.81 per cent) responded. All statistics were computed using the SPSS computer software.

Findings - The organizational variables of the SMEs such as membership and ownership structure, leadership, policies, systems and procedures, resource mobilization, linkages and networking, communication systems and awards and recognition were assessed to be all "good" and were found to have significant relationship with the level of empowerment of rural communities with SMEs.

Originality/value - The rural communities with SMEs were empowered along the aspects of material, perceptual and relational changes. The result of the study indicated that through SMEs, rural people experienced changes in their lives. The test about the relationship of the organizational variables such as nature and ownership of business enterprise, leadership, policies, systems and procedures, resource mobilization, linkages and networking, communication systems and awards and recognition

(C) Asterio Tenedero Miranda and Juneth Lourdes Fiel Miranda. Published in the Asia Pacific Journal of Innovation and Entrepreneurship. Published by Emerald Publishing Limited. This article is published under the Creative Commons Attribution (CC BY 4.0) licence. Anyone may reproduce, distribute, translate and create derivative works of this article (for both commercial and noncommercial purposes), subject to full attribution to the original publication and authors. The full terms of this licence may be seen at http://creativecommons.org/licences/by/4.0/legalcode

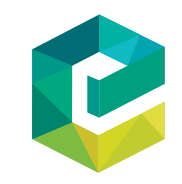

Asia Pacific Journal of Innovation and Entrepreneurship Vol. 12 No 1,2018 12 No. 1,2018
pp. $105-119$ pp. 105-119
Emerald Publishing Limited 2398-7812 DOI 10.1108/APJE-12-2017-0045 
APJIE 12,1 and the level of empowerment of rural communities as determined by changes in the material, perceptual and relational aspects of rural life proved to have significant relationships.

Keywords Empowerment, Small and medium enterprises, Rural communities

Paper type Research paper

\section{6}

\section{Background of the study}

In the Philippines, there is an increasing recognition of the important role played by the small and medium enterprises (SMEs) to promote growth, which is not limited to the simple creation of wealth or capital. They are vital to dispersing new industries to the countryside and stimulating employment. They are more likely to be labor intensive, thus providing jobs wherever they are established. In this sense, they bring about more balanced agro-industrial growth and equity in income distribution (BSMBD, 1996 as cited by Egay and Bolla, 1999; Mendoza, 2001).

Mallari (2000) emphasized that SMEs are recognized by the Philippine Government as the cornerstone of economic growth. In particular, the government has enacted the Republic Act 8289, also known as the Magna Carta for Small Enterprises, which aims to support and strengthen the SMEs development, particularly those that are rural and agriculture-based. The sector contributes about 33 per cent to the country's economic growth and employs about 67 per cent of the labor force. The role of the SMEs in the economy's growth is very vital. They contribute to a more equitable distribution of income, disperse economic activities to the country side and most importantly, SMEs are potent forces in the war against poverty.

In rural communities, business establishments such as the SMEs can be a source of power, more so, if they are making a dent on the lives of a significant number of rural people. Obviously, SMEs have the capacities and capabilities to generate employment and income that at the very least will provide the people fair chances of accessing, owning and controlling resources. Through employment and income that SMEs can provide, people get opportunities of availing improved services on health, nutrition and education and further maximize their potential toward availing better facilities on housing, water and power supply. The emergence and growth of SMEs in rural communities becomes evident when the needed support mechanisms that will set the business environment more conducive to business operations are in place. Trade policies, for example, should encourage investors to establish, develop and expand their businesses. Other factors that may prove beneficial to the emergence of SMES such as the presence of credit institutions with good lending packages; the technical intervention and support from the government and private sectors such as capability building and skills enhancement programs to equip and capacitate the management and staff of the SMEs on the intricacies of business management.

\subsection{Objectives of the study}

This study sought to determine the status and conditions of SMEs as predictors in empowering the rural communities of Samar Island, Philippines. Specifically, it aimed to describe the organizational variables of SMEs and assess their conditions in terms of membership/ownership structure; leadership; policies, systems and procedures; resource mobilization; linkages and networking; communication systems; and awards and recognition; determine the level of empowerment of rural communities with SMEs in terms of material, perceptual and relational changes; and find out the degree of relatedness of organizational variables to the level of empowerment of rural communities with SMEs. 


\section{Literature review}

\subsection{Definition of small and medium enterprises}

Hobbs and Del Rosario (2000) claims that there is no consensus on the definition of SMEs throughout the Asia-Pacific region owing to the differences in the general economic development within each country and their prevailing social conditions. Various indices are used by member economies, including number of employees, invested capital, total amount of assets, sales volume and production capability. Other classifications exist too, contributing to confusions in definitions. For example, in China, a distinction is made between SMEs and Township and Village Enterprises (TVEs). In Chinese Taipei, definitions vary with respect to those that expect to receive government assistance. Singapore classifies according to local and overseas SMEs. There are many definitions and classification of SMEs throughout Asia but the most commonly used is the number of employees: 10-500 is the average number.

In his study about the institutionalization of agro-based SMEs in Batangas Province, Philippines, Mendoza (2001) has presented the following published definitions of SMEs of the nine countries; eight use employment size as the basis of classification, and among the eight countries, five have alternative bases such as asset and capital size, in addition to employment size (Table I).

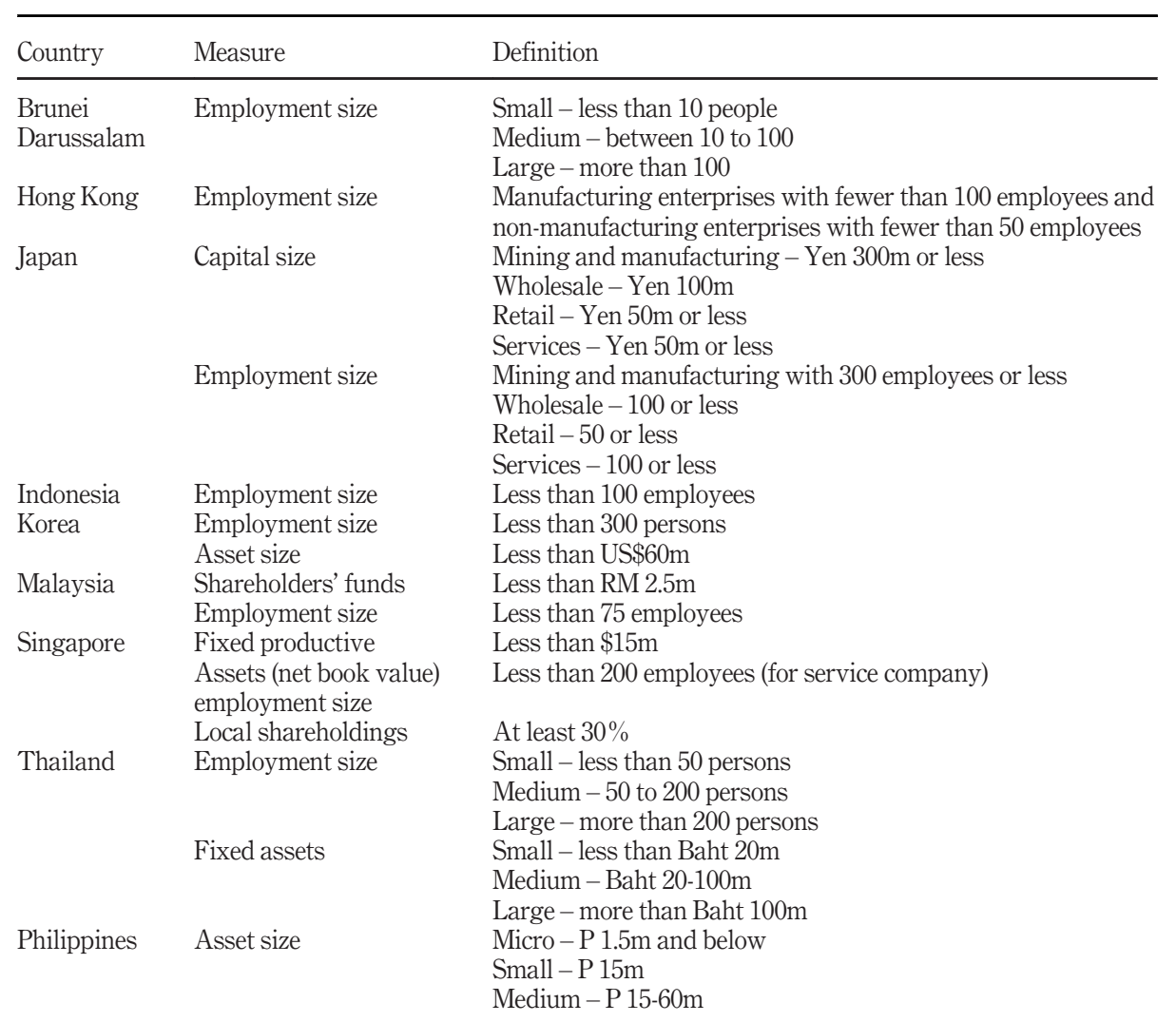

Table I.

Definition and classification of SMEs in Asia based on asset, capital, and employment size 
APJIE

12,1

The People's Republic of China (PRC) has a new standard for classifying large-, mediumand small-sized enterprises. The basic criteria for scaling enterprises of various industrial sectors are annual sales and fixed assets. Both the annual sales and the fixed assets of a large-sized enterprise should exceed Yuan 5bn, while those of a medium-sized enterprise should exceed Yuan 5m; otherwise, an enterprise will be categorized as a small-sized enterprise.

Moreover, Mendoza (2001) emphasized that in the Philippines, the definition of SMEs has evolved over the years but always on the basis of either asset size or the number of employees. The current definition is provided in Republic Act No. 8289, enacted on July 22, 1996 to strengthen the promotion and development of, and assistance to small and medium enterprises. As defined in the act, a small and medium enterprise is any business activity or enterprise engaged in the industry, agribusiness and/or services, whether single proprietorship, cooperative, partnership or corporation whose asset size corresponds to the set amounts as follows:

- Micro P1,500,000 and below.

- Smallfrom P 1,500,001 to P 15m.

- Mediumfrom P 15,000,001 to P 60m.

Republic Act No 6977, enacted on July 23, 1990, otherwise known as the Magna Carta for Small Enterprises used the following categories in classifying business enterprises:

- Microless than P 50,000.

- Cottagefrom P 50,001 to P 500,000.

- Smallfrom P 500,001 to P 5m.

\subsection{Small and medium enterprises in the Philippines}

The government's commitment to promote small enterprises as a policy for growth is formally made explicit in the recently approved Magna carta for Small Enterprises, which seeks the following:

To promote, develop, and assist small and medium-scale enterprises through the creation of a small and medium enterprise development (SMED) council, and the rationalization of government assistance programs and agencies concerned with the development of small and medium enterprises, and for other purposes (Lapar, 1991).

On the basis of the latest available statistical data provided by the Philippine Statistics Authority (PSA) (2015), there are 900,914 establishments in the Philippines. Of these, 99.5 per cent $(896,839)$ are micro, small and medium enterprises (MSMEs), and the remaining 0.5 per cent $(4,075)$ is large enterprises. Majority of the 896,839 MSMEs in 2015 were in the wholesale and retail trade; the business establishments engaged in the repair of motor vehicles and motorcycle industries, accommodation and food service activities, manufacturing, other service activities, information and communication, and financial and insurance activities were 417,094; 119,037;113,949; 56,904; 35,171; and 34,384, respectively. These industries accounted for about 87.0 per cent of the total number of MSME establishments. Majority of the MSMEs in operation in 2015 can be found in the National Capital Region (NCR), with 190,166 business establishments; Region 4-A (CALABARZON), 131,011; Region 3 (Central Luzon) with 100,880; Region 7 (Central Visayas) with 53,218; and Region 1 (Ilocos), 47,996. These top five (5) locations accounted for about 58.4 per cent of the total number of MSME establishments in the country. MSMEs generated a total of 4,784,870 jobs in 2015 as compared to 2,981,819 for large enterprises. This indicates that MSMEs 
contributed almost 61.6 per cent of the total jobs generated by all types of business establishments that year. Of these, 29.4 per cent or 2,285,634 jobs were generated by micro enterprises; 25.3 per cent or 1,968,452 by small enterprises; and 6.8 per cent or 530,784 by medium enterprises. MSMEs accounted for 25 per cent of the country's total exports revenue. It is also estimated that 60 per cent of all exporters in the country belong to the MSME category. MSMEs were able to contribute in exports through subcontracting arrangement with large firms, or as suppliers to exporting companies.

\subsection{Concepts of empowerment}

The term empowerment has different meanings in different social and political contexts and does not translate easily into all languages. An exploration of the local terms for empowerment around the world always leads to lively discussions. Local terms associated with empowerment include self-strength, control, self-power, self-reliance, own choice, life of dignity in accordance with one's values, capability to fight for one's rights, independence, own decision-making, being free, awakening and capability.

Among many Filipino organizers, empowerment is tuklas-lakas, which literally means discovering power. In the process of discovering, the poor regain their humanity and critically re-discover that they are of value not for what they have or don't have but for what they are. Their dignity is enhanced through the practice of their capacity to share their own future. According to Espinar and Company (2001), empowerment signifies the awakening and utilization of the innate power and potential that belong naturally to persons and collectivities. Empowerment, according to her, is equated with community organizing (CO). $\mathrm{CO}$ is organizing people for power, and it is a continuing process of empowering the people so that benefits consistent with their priorities and aspirations will sustainably accrue to them.

Empowerment is of intrinsic value. It also has instrumental value. It is relevant both at the individual and collective level. It can be used to characterize relations within households or between poor people and other actors at the global level. The World Bank (2002) operationally defines empowerment as the expansion of assets and capabilities of poor people to participate in, negotiate with, influence, control and hold accountable institutions that affect their lives. In its broadest sense, it is the expansion of freedom of choice and action. It means increasing one's authority and control over the resources and decisions that affect one's life. As people exercise real choice, they have increased control over their lives.

Fernandez (1994) defines empowerment as a process that entails the transfer of power to the people for decision-making and policy formulation, premised on a commitment to a more egalitarian society. People empowerment, according to him, focuses on the development of the marginalized individuals in the community to participate in all spheres of decisionmaking, i.e. social, political and economic. This entails the establishment and consolidation of self-reliant people's organizations, which could sustain the development process and increase the power of the majority to respond to the problems, issues and needs by themselves.

\subsection{Elements of empowerment}

There are thousands of examples of empowerment strategies that have been initiated by poor people themselves and by governments, civil society and the private sector. Although there is no single institutional model for empowerment, experience shows that certain elements are almost always present when empowerment efforts are successful. The four elements of empowerment that must underlie institutional reform are: access to information, inclusion and participation, accountability and local organizational capacity. These four
Small- and medium-sized enterprises as predictors 
APJIE 12,1

elements are closely intertwined and act in synergy. Thus, although access to timely information about programs, or about government performance or corruption, is a necessary precondition for action because there are no institutional mechanisms that demand accountable performance or because the costs of individual action may be too high. Similarly, experience shows that poor people do not participate in activities when they know their participation will make no difference to products being offered or decisions made because there are no mechanisms for holding providers accountable, even when there are strong local organizations, they may still be disconnected from local governments and the private sector, owing to lack of access to information (The World Bank, 2002).

Ramos (1991) emphasized that empowerment does not mean political empowerment alone. It also means economic empowerment, social empowerment, cultural empowerment, all of which contribute to national empowerment. If local communities are to have any power over their own lives according to him, then they must be allowed to consolidate, use and develop their own resources.

Ford (1987), as cited by Poblete (1995), identified various aspects of empowerment such as physical, intellectual, economic, political and cultural. It requires a shift in the possession of authority or influence as well as the control of goods and services from the traditional centers of power to other newly created centers. In this manner, power is no longer a monopoly of certain individuals or groups in a given society. Hence, empowerment is a process of increasing the capabilities of people for decision-making and problem-solving.

\subsection{Community empowerment}

Empowering rural communities is necessary to create a brighter future. It involves five things:

(1) knowledge of existing conditions;

(2) a vision for the future;

(3) a constituency of people;

(4) a commitment to act; and

(5) a plan for taking action.

First, residents need to understand current community trends and the long-term implications of these trends. Second, thy need to develop a vision for the future - the biblical adage "without a vision the people perish" is true. Third, there needs to be a constituency of people; it need not be a majority, but it must be a group large enough to build momentum and energize others. Fourth, there must a commitment to act; talking is important but action is even more critical. Finally, there must be some plan, which guides the action or lends direction to the people involved. All five of these components are important but it is critical that a vision and a plan get translated into action: empowerment in essence, means enabling people to act (Goreham, 2002).

The World Bank, 2002 emphasized that since time immemorial, groups and communities have organized to take care of themselves. They work together, organize themselves and mobilize resources to solve problems of common interest. Often outside the reach of formal systems, poor people turn to each other for support and strength to solve their everyday problems. Poor people's organizations are often informal, as in the case of a group of women who lend each other money or rice. They may also formal, with or without registration, as in the case of farmers' groups or neighborhood clubs. Around the world, including in war torn societies, the capacity of communities to make rational decisions, manage funds and solve problems is greater than generally assumed. Organized communities are more likely to have 
their voices heard and their demands met than communities with little organization. Poor people's membership-based organizations may be highly effective in meeting survival needs, but they are constrained by limited resources and technical knowledge. In addition, they often lack bridging and linking social capital; that is, they may not be connected to other groups unlike themselves or to the resources of civil society or the state. It is only when groups connect with each other across communities and form networks or associations eventually becoming large federations with a regional or national presence - that they begin to influence government decision-making and gain collective bargaining power with suppliers of raw materials, buyers and financiers.

\subsection{Empowerment indicators}

Domingo (2000) cited Foa and Foa (1974) who identified resources as one of the factors that influence empowerment. They found out that the resource chosen for reciprocation is influenced not only by the resources previously received but also by institutional setting in which the exchange take place. On the whole, the study indicated that when no constraints are imposed on the availability of resources, certain exchanges are more likely to occur than others.

Empowerment is dependent on four interdependent variables (CDRA, 1987) such as follows:

(1) the sense of community which refers to the attachment between people and their social milieu through shared history, value systems and reinforcement of common experiences;

(2) the competence in collective identification of problems and needs and consensus on the ways and means to implement agreed goals;

(3) human and material resources that are called upon or mobilized in the face of adversity; and

(4) the level of community/social participation in decision-making process.

Enterprises can be a source of power. Tan (1995) emphasized the importance of developing spirit and a sense of personal achievement, which can be attributed to three essential and interrelated factors: environment, economic relationships and experience.

An environment conducive to developing entrepreneurs is characterized by the following:

- freedom to pursue and transfer ideas; presence of an open market where individual can express their ideas in an infinite variety of products;

- minimum restrictions from authorities that allow the pursuit of interest, with available support from the community; and

- access to materials and technologies for product development.

Economic relationships have something to do with networking, which the entrepreneurs must learn much. They must also learn to develop skills in listening, respect for others and appreciation for the help given. Most importantly, they need to learn not to betray other's trust. More than a competitive spirit, entrepreneurship imbibes a sense of cooperation. Entrepreneurial experience, on the other hand, is an acquired learning by applying a specific knowledge to practice. One may never become an entrepreneur without hands-on experience. Substantive learning is increased, and self-esteem enhanced, when new insights and discoveries are gained by self-learning. This experience can be acquired in any work
Small- and medium-sized enterprises as predictors 
APJIE

12,1

area and becomes entrepreneurial when ideas are transformed in an innovative way (Tan, 1995).

Any empowerment process involves a complex combination of different dimensions and levels. Empowerment frameworks have typically combined indicators of empowerment, equality and equity. In the review of materials on empowerment indicators, the researchers adopted the indicators espoused by Chen (2002). Chen had developed three major empowerment indicators, which he had applied in his study to measure the impact of microfinancing activities, such as:

- Material change: Income - (which is measured in terms of) increase in income and income security; resources - increase access to, control over and ownership of assets and income; basic needs - increase or improvement in health care, child care, nutrition, education, housing, water supply, sanitation and energy source; earning capacity - increase employment opportunities plus the ability to take advantage of these opportunities.

- Perceptual change: Self-esteem - enhance perception of own individuality, interest and value; self-confidence - enhance perception of own ability and capacities; vision of future - increase ability to think ahead and plan for the future; visibility and respect - increase recognition and respect for individual's value and contribution.

- Relational change: Decision-making - increase role in decision-making within household and community; bargaining power - increase bargaining power; participation - increases participation in nonfamily groups, in local institutions, in local government and political process; self-reliance - reduce dependence on intermediation by others for access to resources, markets, public institutions plus increase in the ability to act independently; organizational strength - increase strength of local organizations and local leadership.

\section{Methodology}

This study is a descriptive survey, which used an interview schedule and structured survey questionnaire as the main sources of data. It used a multistage sampling procedure.

\subsection{Stage 1 - primary sampling units}

3.1.1 Selection of small- and medium-sized enterprises sub-sectors. (All DTI-registered SMEs in rural barangays of the different municipalities in the three provinces of Samar Island).

Sampling scheme:

Purposive sampling by selecting three (3) SME sub-sectors that best meet the following criteria: (a) most prevalent in the province, (b) operational for the last five years, (c) possess asset size of at least P100,000.00 and (d) with manpower complement of at least five.

Sample size: $n=3$ sub-sectors of SMEs per province.

\subsection{Stage 2 - secondary sampling units}

3.2.1 Listing of small- and medium-enterprises from the three sub-sectors. Sampling scheme:

Simple random sampling consists of six enterprises from the three sub-sectors per province, namely, manufacturing, trading and service sectors.

Sample size: $n=18$ enterprises. 
There were 15 respondents sampled per enterprise, representing the three groups: 5 from the management and staff of the SMEs, which were drawn through simple random sampling using the lottery technique, and 5 from the community households, which were drawn through a household count in the community taking into consideration the proximity in the area where the SME is established, and 5 institutional representatives from the Department of Trade and Industry (DTI), Local Government Unit (LGU), Department of Education, Culture and Sports (DECS), Non-Government Organizations (NGOs) and Church or religious institutions. Each institution had one representative:

Sample size: $n=15$ respondents per enterprise.

Total $=270$ respondents ( 15 respondents $\times 18$ enterprises).

On the basis of the target, 18 or 100 per cent of the SMEs participated in the study involving 256 , out of 270 respondents, which constituted 94.81 per cent.

The survey instrument was translated into Samarnon purposely to elicit the desired data for the study. The translated version of the survey instrument was pre-tested in the 3 rural communities with reported existing SMEs in Northern Samar involving 43 respondents. Pretesting allowed certain revisions of some items in the instrument before they were used in the actual survey.

There were personal interviews conducted with the management and staff to establish the profile of the community organization. Their responses were validated from the available documents such as minutes of meeting, policy manuals, financial reports and other pertinent records of the organizations. To rate the status and conditions of the SMEs in terms of membership and ownership structure, leadership, policies, systems and procedures, resource mobilization, financial resources, linkages and networking, communication system and awards and recognition, a rating scale of 1-4 was used, in ascending order.

To show the extent of agreement or disagreement of the respondents on the different items used by the researcher to measure the empowerment levels of the rural communities, a set of structured questionnaires was used.

The empowerment levels of rural communities in terms of the changes in the material, perceptual and relational aspects were evaluated using the scale of 1-disagree to 4-strongly agree.

Descriptive statistics such as frequency counts, and percentages, ranking and weighted means were used in describing the data gathered in this study. Inferential statistics was used to determine the relationship of the independent variables to the level of empowerment of rural communities, the dependent variable. The rural community with SME was the unit of analysis in this study. All data analyses were done using the SPSS computer software.

This study tried to bring into fore the presumed relationship of the following:

H01. The organizational variables such as membership and ownership structure of business enterprise, leadership, policies, systems and procedures, resource mobilization, linkages and networking, communication systems and awards and recognition are not related to the level of empowerment of rural communities as determined by the changes in the material, perceptual and relational aspects of rural life.

\section{Results and discussion}

4.1 The status and conditions of small and medium enterprises in the rural communities

4.1.1 Status of small and medium enterprises. Of 18 SMEs covered by the study seven are single proprietorship, six primary cooperatives, two corporations, two partnerships and one 
APJIE 12,1

NGO/PO. The average number of years that these SMEs have been in operation was 12 years. The highest however was 29 years, while the lowest was 5 years. The oldest registered SME came from Eastern Samar, having been registered for 29 years with the Department of Trade and Industry (DTI). The SME with the latest registration came from Northern Samar, having sought its registration in 1999, with the Cooperative Development Authority (CDA), a year after its organization and operation. The average number of personnel that these SMEs have is 23, with 105 as the highest and six as the lowest.

4.1.2 Membership/ownership structure. Single proprietorship. Out of the seven SMEs registered as sole proprietorship, four are from Eastern Samar; two from Samar; and one from Northern Samar. In terms of capital structure, majority had (71.43 per cent) have loans coming from financing institutions particularly banks and government agencies, aside from their own investments as working capital for business operations.

Cooperatives. The total original members of the six cooperatives totaled 2,474, with 94.75 per cent of them active and the rest, inactive. About 98.87 per cent of the members have share capital or investment, an indication that the members realize the importance and benefits of putting up capital or investment in the cooperative.

The average number of members transacting business within a month posted about 258, with the cooperatives from Samar province indicating the highest number of 822, out of 830 total present members. The lowest was also coming from a cooperative in the Samar province, with 14 out of 75 total present members.

Partnership, Corporation and NGO/PO. The original partners or incorporators of the five SMEs registered as partnership (2), corporation (2) and NGO/PO (1), totaled to 28 , with 57.14 per cent male members and 42.56 per cent female. The present membership is $35,94.29$ percent of whom are active. Most (79.29 per cent) have capital investment, and 62.85 per cent transact business with the organization within a month.

4.1.3 Leadership. The leadership of the 7 SMEs registered as single proprietorships were all vested on the owners themselves, and in terms of their academic qualifications, four are college graduates, while the other three are college levels. All are males; six have been managing their business enterprises since their inception, while the other one has barely two years of experience in the actual business operations.

For the 11 SMEs registered as cooperatives, corporation, partnership and NGO, the highest number of Board of Directors/trustees was nine, coming from the two cooperative enterprises, while the lowest was three, coming from the two partnership ventures. Almost all of the members of the Board of Directors/Trustees work with their respective business organizations. The Board of Directors/Trustees of these 11 SMEs are college graduates; mostly with one-year term of office. The majority (90.90 per cent) conduct election as a process of selecting the officers/leaders, while only one practice the appointment process.

4.1.4 Policies, systems and procedures. Most of the 18 SMEs generate financial resources from internal sources primarily in the form of share capital or fixed deposit. Aside from the internally generated funds, 9 or 50 per cent of the SMEs generate financial resources from external sources by availing loan from the banks and other lending institutions. There were four SMEs, three cooperatives and one NGO, which availed of grants and donations from funding agencies both local and national. Only seven (38.39 per cent) of the SMEs implemented resource mobilization programs with the involvement of the member-owners and investors, the majority (61.11 per cent) did not. 
4.1.5 Linkages and networking. Majority (72.22 per cent) of the SMEs have established linkages with different institutions. Six are linked with NGOs; another six with the GOs; five are linked with trade organizations; two with the academe; and the rest with people's organizations. The linkages focused primarily on technical assistance, financial assistance and marketing linkage.

Only seven (38.89 per cent) of the SMEs had sought membership with an alliance or a network. Out of the 7,71. 43 per cent were cooperatives being affiliate members of Visayas Cooperative Development Center-National Confederation of Cooperatives (VICTO-NATCCO), Bahandi Producers of Eastern Visayas, Grains association and two are NGO and proprietorship having sought membership with the Alliance of Local Producers such as Coir Industry of the Philippines and Samar Products Association.

4.1.6 Communication system. Majority (77.78 per cent) of the SMEs used verbal communication in the management of their internal affairs. As to the means of contact during meetings and other related activities, 88.89 per cent used personal contact; while one utilizes its own cable TV thru plugs. Frequently used communication facilities by the majority of the SMEs were telephones/cellular phones and typewriters while one uses base radio. There were two SMEs that did not use any communication facility for their business operations.

4.1.7 Awards and recognition. Out of 18, only 33.33 per cent have joined in contests and competitions and won. These were three cooperatives. The rest were sole proprietorship (1), partnership (1) and NGO (1). The cooperatives won awards: Most Outstanding Cooperative, with two municipal and provincial level awards and another one at the regional level; Best Store of the Year and Best in Savings and Credit, both at the provincial levels; Top Seller Award and Most Promising Product Design, both at the national level and at the same category (institutional Category). The sole proprietorship involved in the steel craft and welding shop operations won in the Search for the Best Steel Craft Design at the regional level; the NGO won the Top Seller Award at national level (institutional category); and the partnership venture, participated in the summer sports competition and emerged as the winner.

4.1.8 Conditions of small and medium enterprises. The assessment made by the respondents on the condition of the SMEs revealed that all organizational variables such as nature of membership and ownership structure; leadership; policies, systems and procedures; resource mobilization; linkages and networking; communication systems and awards and recognition were assessed as "good" (Table II).

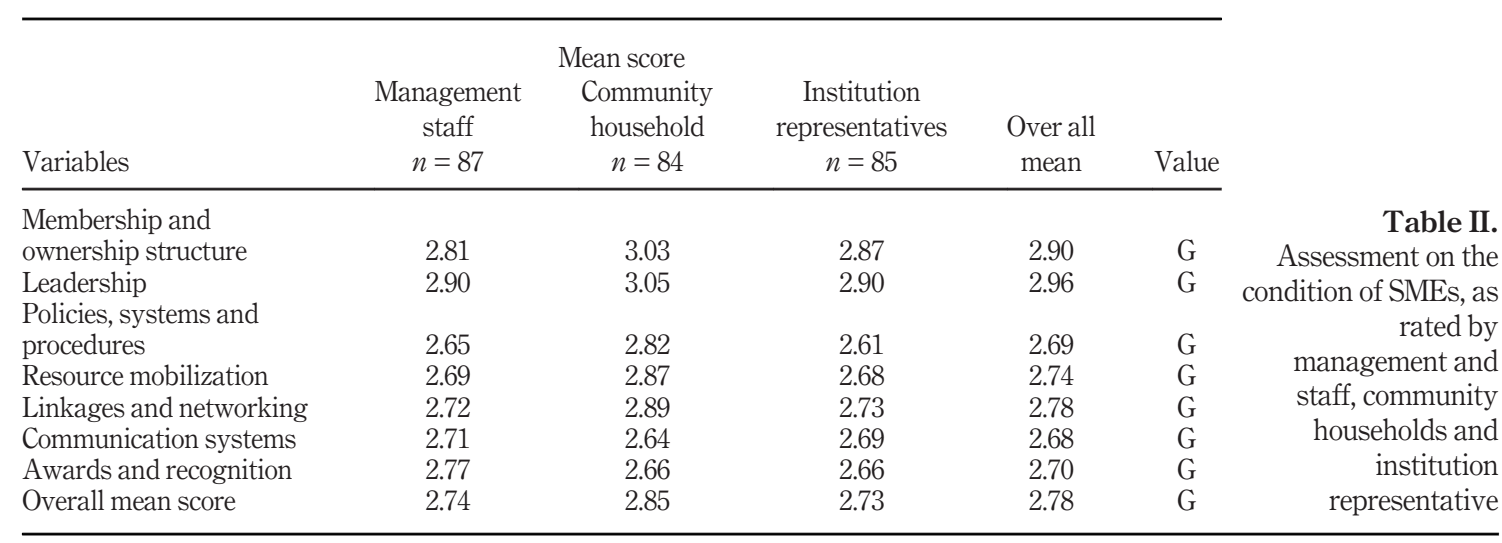

Small- and medium-sized enterprises as predictors

115

\section{.}


APJIE

12,1

\section{6}

Legend:

- 1:00-1.75Poor (P).

- 1.76-2.50Fair (F).

- 2.51-3.25Good (G).

- 3.26-4.00 Very Good (VG).

\section{Level of empowerment of rural communities with small and medium enterprises}

The rural communities with SMEs were empowered along the aspects of material, perceptual and relational changes. The result of the study indicated that through SMEs the rural people experienced changes in their lives. On the material aspect, the SMES provided employment opportunities that helped rural people increase and sustain their income and gave them fair chances of accessing, controlling and owning assets; of availing quality services on health care, nutrition and education. On the perceptual aspect, the SMEs helped rural people develop their self-esteem; enhance perception of their own individualities, interests and values; and increase recognition and respect for individual's value and contribution, and their capabilities toward thinking ahead and planning for the future. On the relational aspect, the rural people appreciated the contribution of the SMEs toward increasing the role of the people in decision making, bargaining power, and participation in the political process. Furthermore, the SMEs are instrumental in providing strengths to local organizations and leadership, and in increasing appreciation among rural people that the SME is a tool toward achieving self-reliance (Table III).

Legend:

- 1:00-1.75Not empowered.

- 1.76-2.50Slightly empowered.

- 2.51-3.25Empowered.

- 3.26-4.00Strongly empowered.

\section{Test of relationships}

The hypothesis that the organizational variables (nature and ownership of business enterprise, leadership, policies, systems and procedures, resource mobilization, linkages and networking, communication systems and awards and recognition) are not related to the level of empowerment of rural communities, as determined by changes in the material, perceptual

Table III.

Assessment on the level of empowerment of SMEs in terms of material, perceptual, relational changes as rated by the management and staff, community households and institution representatives

\begin{tabular}{|c|c|c|c|c|c|}
\hline Criteria & $\begin{array}{c}\text { Management } \\
\text { staff } n=87\end{array}$ & $\begin{array}{c}\text { Mean score } \\
\text { Community } \\
\text { house-hold } \\
n=84\end{array}$ & $\begin{array}{c}\text { Institution } \\
\text { representatives } \\
n=85\end{array}$ & $\begin{array}{c}\text { Over all } \\
\text { mean }\end{array}$ & Value \\
\hline Material Change & 2.67 & 2.83 & 2.65 & 2.72 & Empowered \\
\hline Perceptual change & 2.80 & 2.89 & 2.78 & 2.82 & Empowered \\
\hline Relational change & 2.80 & 2.97 & 2.74 & 2.86 & Empowered \\
\hline Overall mean score & 2.78 & 2.90 & 2.72 & 2.80 & Empowered \\
\hline
\end{tabular}


and relational aspects of rural life, was disconfirmed indicating that the organizational variables are all related or associated with the level of empowerment (Table IV).

\section{Implications and recommendations}

The enactment of Republic Act 9178, otherwise known as the Barangay MicroBusiness Enterprises (BMBEs) Act of 2002, is a positive step by the Government in its efforts to spur economic development in the countryside by encouraging the formation and growth of BMBEs, aside from the SMEs. The law defines BMBE (Section 3, a of RA 9178) as a business entity or enterprise engaged in the production, processing or manufacturing of products or commodities including agro-processing, trading and services whose total assets including those arising from loans but exclusive of the land on which the particular business entity's office, plant and equipment are situated, shall not be more than P 3,000,000.00.

In this regard, enterprises whose asset sizes do not qualify as SME can now be reregistered as BMBEs where they can avail of the credit windows that will serve their financial needs from any of the mandated agencies of the government. Moreover, the BMBEs once registered, will be exempted from paying income taxes for income arising from the operations of the enterprise, and from the coverage of the minimum wage law.

\subsection{Organization and establishment of Samar-wide trade association or chamber of commerce}

Collaborative efforts among the three provincial offices of the Department of Trade and Industry in Samar Island should be directed toward the organization and establishment of a Samar-Wide Trade Association or Chamber of Commerce. The said association will ensure that the rights, benefits or privileges of the SMEs/BMBEs particularly in Samar Island are vigorously pursued and the interests of the owners/entrepreneurs are being protected.

\subsection{Establishment of an inter-agency regional small and medium enterprises development center}

To strengthen the capabilities and capacities of the SMEs and BMBEs in region 8, along the areas of enterprise development and implementation management, it is recommended that a Regional SME Development Center be established. The University of Eastern Philippines and the Department of Trade and Industry of

\begin{tabular}{|c|c|c|c|c|c|c|}
\hline Variables & Computed & $\begin{array}{l}\text { lue } \\
\text { Tabulated } \\
\text { value } 5 \%\end{array}$ & $\begin{array}{l}\text { Degree of } \\
\text { freedom }\end{array}$ & Decision & Interpretation & \multirow{7}{*}{$\begin{array}{r}\text { Table IV. } \\
\text { Degree of relatedness } \\
\text { of the organizational } \\
\text { variables to the level } \\
\text { of empowerment of } \\
\text { rural communities } \\
\text { with SMEs }\end{array}$} \\
\hline \multicolumn{7}{|l|}{ Membership and } \\
\hline Leadership & 183.85 & 16.92 & 9 & Rejected Ho & Related & \\
\hline $\begin{array}{l}\text { Policies, systems and } \\
\text { procedures }\end{array}$ & 106.14 & 16.92 & 9 & Rejected Ho & Related & \\
\hline $\begin{array}{l}\text { Resource mobilization } \\
\text { Linkages and }\end{array}$ & 170.06 & 16.92 & 9 & Rejected Ho & Related & \\
\hline networking & 184.10 & 16.92 & 9 & Rejected Ho & Related & \\
\hline Communication systems & 66.82 & 16.92 & 9 & Rejected Ho & Related & \\
\hline Awards and recognition & 54.35 & 16.92 & 9 & Rejected Ho & Related & \\
\hline
\end{tabular}

Small- and medium-sized enterprises as predictors 
Region 8 will spearhead this, in collaboration with other agencies of both government and the private sector, including federation or union of trade associations and/or chambers of commerce.

\subsection{Research recommendations}

On the basis of the findings of the study, it is recommended that similar studies be conducted in other regions of the country to derive findings that may either support or refute the conclusions arrived at. These studies would cover more enterprises in the service sectors such as, but not limited to, the emerging information and communication, finance and insurance services.

\section{References}

Bureau of Small and medium Business Development (BSMBD) (1996), Small Business in the Philippines, Trade and Industry Information Center, Makati City.

Chen, N. (2002), "Empowerment indicators in enterprise development", available at: www.enterpriseimpact.org (accessed 16 August 2002).

Community Development Resource Association (CDRA) (1987), Indicators of Participation and Empowerment, Community Development Resource Association (CDRA), Woodstuck.

Domingo, L. (2000), "Empowerment and sustainability of selected farmer cooperatives in Isabela, Philippines", Unpublished Dissertation, University of the Philippines Los Banos, College, Laguna.

Egay, L. and Bolla, M.F.E.M. (1999), "SMEs and their impact on poverty alleviation", Country Report, Regional Seminar on Small Rural Industries in a Liberalized Economic Environment and the Impact of Globalization on Poverty Alleviation, Trivandrum, 31 August to 3 September 1999.

Espinar, H.F. and Company (2001), Project management. "Reference materials for PACAP-NGO/PO partners: a compilation of reference materials", Revised edition, Materials prepared for Australian Embassy- USAID/PACAP, September 2001.

Fernandez, R.B. (1994), "Empowering CARP beneficiaries through cooperatives and people's organizations: a strategic analysis", Unpublished Masteral Thesis, National Defense College of the Philippines, Fort Bonifacio, Metro Manila.

Foa, U.G. and Foa, E.B. (1974), Societal Structures of the Mind, Charles C. Tomas, Oxford.

Goreham, G. (2002), "Engaging leaders in community learning”, available at: www.gary.goreham@ ndu.nodak.edu (accessed 2 May 2002).

Hobbs, J. and Del Rosario, T. (2000), Promoting Cleaner Production in Small and Medium-Sized Enterprises, SME and Environment, Green Leaf.

Lapar, M.L.A. (1991), "Growth and dynamics of small and micro enterprises: does finance matter?", paper presented in the Consultation Workshop on the Dynamics of Rural Development, Philippine Institute for Development Studies, Tarnate, Cavite, 30-31 August.

Mallari, R. (2000), "SMEs adapt to survive”, Asian Business, August, p. 44.

Mendoza, R.R. (2001), "Institutionalization of Agri-based Small and Medium Enterprises (SMEs) in Batangas Province, Philippines", Unpublished Dissertation, University of the Philippines Los Banos, College, Laguna.

Philippine Statistics Authority (PSA) (2015), “2015 MSME statistics”, available at: www.dti.gov.ph/dti/ index.php/2014-04-02-03-40-26/news-room/179-workshop-on-market-access-for-smes-set (accessed 5 December 2017). 
Poblete, T.O. (1995), "The empowerment of local community organizations in selected areas of Laguna”, Unpublished Dissertation, University of the Philippines Los Banos College, Laguna.

Ramos, F.V. (1991), Power to the People to Win the Future: People Empowerment for National Development: A Collection of Speeches by the President of the Philippines, Published by the Friends of Steady Edie, Iloilo City.

Tan, Q.G. (1995), "Management update: entrepreneurship-corporate entrepreneurs, like business entrepreneurs are made: a featured article", The Asian Manager, April-May 1995, pp. P16-P18.

The World Bank (2002), "A framework for empowerment”, available at: www.worldbank.org (accessed 1 May 2002).

\section{Corresponding author}

Asterio Tenedero Miranda can be contacted at: asteriomirandajr@yahoo.com
Small- and medium-sized enterprises as predictors

For instructions on how to order reprints of this article, please visit our website: www.emeraldgrouppublishing.com/licensing/reprints.htm Or contact us for further details: permissions@emeraldinsight.com 